\title{
Rehabilitated Returners: Why Some Older Women Re-affiliate to the Christian Church
}

\author{
JANET ECCLES \\ Lancaster University
}

\begin{abstract}
Much has been written about the persistent and rapid decline of churchgoing among all sections of the British population, women as well as men, although women still constitute the majority in most congregations (Brierley 2003; 2006; Brown 2001; 2006; 2010; Bruce 2002; Crockett \& Voas 2006; Heelas \& Woodhead 2005; McLeod 2007). Rather less attention has been paid in Britain to returning to churchgoing. The article considers the cases of a small group of women, aged 40 and upwards, part of a larger study, most of whom have returned to church after a considerable absence, and the reasons they give for their return. Five newer approaches to the study of religiosity are then briefly introduced, the better to explain and analyse the forms taken by this particular renewed commitment within the Christian church in Britain today.
\end{abstract}

Keywords: women, churchgoing, re-affiliation

There is no doubting that churchgoing in Britain continues to be the activity of an ever diminishing band of people, women as well as men. The debates continue as to why this should be so (Brown 2001; 2006; Brown \& Snape 2010; Bruce 2002; Davie 2006; 2007a; Heelas \& Woodhead 2005; McLeod 2007), but much less attention has been paid to church returners. This article is based on part of a larger study, my PhD, carried out between 2004 and 2006 to determine the religious and non-religious commitments of 70 older women who have been brought up Christian but who have also lived through the cultural revolution of the sixties. It was carried out in southern Cumbria, the southern half of the most north-westerly county in England, where I myself live. Findings from my work revealed a sixfold typology of belief/secularity: embedded belongers (Eccles 2010a), rehabilitated returners, reflexive switchers, implicit believers, holistic switchers and secularists (Eccles 2010b). This article focuses on the rehabilitated returners: eleven women who have returned to churchgoing after a period of disaffiliation from the Christian church. 


\section{Context}

The rehabilitated returners form a sub-group among the 38 women who still claimed affiliation to some form of Christian church when I interviewed them. For the study as a whole I spoke to women from a variety of affiliations, from conservative Catholic to progressive spiritual (Lynch 2007), together with some secularists. Many of the women were middle class, but not all. There was only one black participant; this largely rural area of villages and small towns has seen minimal non-white inward migration. There is one post-industrial community, from which participants were also drawn. The interviews were supplemented by observant participation in religious (and secular) settings over a period of six years. I attended worship in some of the churches, together with prayer meetings and ecumenical groups. I studied local church literature and drew on my knowledge of the worshipping communities, gained as secretary of a local ecumenical group.

Women were recruited, initially, from among people I knew, through my considerable involvement in ecumenism across the whole of south Cumbria; but also through my secular activities, such as sitting on charity committees and attending adult education classes, including a yoga class, and thereafter by the snowball method. The interviews were semi-structured at most; usually my opening gambit of inviting the women to tell me something of their religious and spiritual journeys up to then was sufficient to elicit a whole life story, with interventions only for clarification, elucidation or elaboration. The interviews lasted about two hours, mostly in the participant's home, sometimes in mine. My aim was to allow the women to speak for themselves, in as comfortable and relaxed an atmosphere as possible.

Obviously, we need to bear in mind that certain events will be remembered better than others. Dex (1991), citing Peters (1989), points out that 'key' events, such as marriage, childbirth, one's first fulltime job and so on, are more likely to be remembered accurately than for example short terms of employment. The same is likely to hold true of events connected with churchgoing. For those interviewees for whom church attendance is important, events connected with this activity are likely to be remembered much more clearly. Life histories, by their nature, are going to be subjective documents, not the stuff of statistics, but valuable because of what the narrator chooses to tell. However, we also need to bear in mind that people are not always aware of or articulate some important reasons for their thoughts and actions, for example those having to do with class, race and gender.

In analysing the data, I needed to determine how churchgoers differed from one another: differences between the various disaffiliates and be- 
tween affiliates and disaffiliates, other than the obvious one: that roughly half of them still attend church while the other half do not. Gradually, through conversations with my supervisor, through constant re-reading of the interview material and through observation of various participants, I came to identify the six ideal types (Barker 1994; Burger 1976; Clarke 2001) enumerated above. Ideal types are used to stress certain elements common to most cases of the phenomena under discussion; they are not meant to correspond to all of the characteristics of any one particular case, nor are they to be understood as attempts to form empirical social generalisations derived from characteristics and elements of given phenomena. They are used to identify and separate underlying causal factors that are obscured by the interplay of causes which contribute to social environments. As Clarke (2001) explains, when 'messy, complex data about social environments' are appropriately 'simplified by abstraction, they enable explanatory generalisations and models to be developed' (Clarke 2001, 7146). Thus ideal types describe phenomena which empirically exist when certain conditions are fulfilled, 'pretending for the purposes of concept formation' that these conditions are given in all the instances which are intended to be covered by the type. To what extent they are 'actually fulfilled in each instance is problematic'. However, most importantly, they are assumed to be fulfilled to some degree. (Burger 1976, 159-60, emphasis in original.)

The study as a whole is based on 70 women, and thus does not claim to be representative. It is, however, illustrative, and would benefit from further research to confirm or confute the typology at which I arrived. To my knowledge almost no work has been done on the particular group represented here, church returners in England, so it is impossible to state to what extent they represent other returners elsewhere. Currently, 8 per cent of the general population attend church on an average Sunday (Heelas \& Woodhead 2005), in a proportion of roughly two women for every man, although how many of them are returners is unknown. Of the women aged over 40 questioned in the British Social Attitudes Survey of 2008, 20 per cent stated they attended church at least once a month; but, again, it is unknown how many of these are returners. Marler (2008) observes that recent empirical research confirms the generational and overall linear direction of the institutional religious decline in Great Britain, citing Voas and Crockett (2005), Voas (2006) and Crockett and Voas (2006). They conclude that the baby boomer generation, who were mostly raised in religion, are those who are less likely to have remained affiliated, and therefore also less likely to have socialised their children into churchgoing, much as asserted by Brown

1 www.esds.ac.uk (Accessed 14 July 2010) 
(2001). The preboomer and boomer women I describe may therefore be said to be bucking this trend, although it is true in the main that their children are no longer affiliated.

The eleven participants whose life histories form the basis of this article comprise six pre-boomers, all born before 1946, and five boomers, born between 1946 and 1964; they range in age from 40 (in 2004) to 70 plus. All but two have worked outside the home at some stage of their life, although one of the two has been unable to undertake paid work because of disabling illness but has a tertiary education. Some of them have followed a profession; others have undertaken more routine jobs. Only two are 'natives' of Cumbria. The participants' worshipping communities span a range of types: conservative evangelical, charismatic evangelical, the liberal mainstream and a group of progressive liberals, part of the Progressive Christian Network Britain (PCNB). We shall see that it is not a homogeneous group. Some women return and become highly committed, while others return to a more sporadic form of attendance; we shall examine the reasons for these differences. I then consider five newer approaches to the analysis of religious commitments and show how these approaches can enhance our understanding of the nature of this re-affiliation.

Much has been made of the effect of the sixties in influencing women to disaffiliate and/or to turn to more holistic forms of spirituality (Brown 2001; 2006; 2010; Heelas \& Woodhead 2005). McLeod, on the other hand, sees returners as being less influenced by the sixties, especially those who were 'economically successful and/or politically conservative' $(2007,248)$. Some of the women in my study have in fact been influenced by the events of the sixties, although not always positively so; some, as McLeod suggests, have been economically successful and might well be described as politically conservative. For all but one woman there has been either a crisis or an unsettling period at some point in her life, which is largely what has precipitated a seeking for stability and community and hence a return to the church. For the longstanding boomer and preboomer churchgoers in my study, it is family bonds which so bind churchgoers together (see Eccles 2010a; 2010b). For returners, family bonds may well be the source of crisis or conflict - or at the least disagreement. Following this crisis/turning point, returners often meet a particular non-family individual or small group who also happens to go to church and who offers the participant affirmation and support. As a result, some of the participants have returned to churchgoing or have become fully committed, in a way they had not previously been. Others, as we shall see, have returned but have not committed themselves 
fully. The commitments which are made, however, are largely voluntaristic and are not performed out of a sense of duty, contrary to what Brown (2001) has suggested as the chief motivation for attendance in the period up to the sixties. His argument runs that it is the advent of the cultural revolution of the sixties which gave women permission to cast off their previously high commitment to churchgoing, which privileged the pious domestic female. As this model of femininity declined with the introduction of the 'permissive society', women began to leave the church in ever increasing numbers. Churchgoing still remains higher than average in this part of England (Brierley 2010, 2), but there is nonetheless ample evidence of a decline (Brierley 2001; 2003; Brierley 2006), albeit not always reported from a gendered perspective.

\section{Findings}

My research shows that churchgoing with a significant other may thus provide one or more of three types of affirmation and support. It can provide a decent, trustworthy substitute family when one's own is lacking or dysfunctional; it can provide a sense of stability and moral order when the world outside seems disordered and others demonstrate behaviour contrary to what the participant perceives as decent and well intentioned; and it can provide healing and empowerment when one feels hurt and vulnerable. In addition, for all of these women it can also provide respectability. Although Jenkins (1999) is writing about a largely working-class urban community in Bristol, in the west of England, it is possible to apply some of his insights to the notion of churchgoing conferring respectability for these women returning to church. He sees the church as one organisation which stands apart from society at large, making public the claims as to the sort of person who can join. Membership proclaims a certain quality of person, showing who you are by whom you spend time with. As he points out, and as I have observed of longstanding churchgoers (Eccles 2010a; 2010b), members of a church represent certain respectable values: thrift, honesty, industry, sobriety and providence. Thus an individual's choice to join such an organisation marks a decision to join the respectable elite; there is a natural correspondence between membership and the 'right sort of person', each quality makes the other. Jenkins also notes, as I have similarly observed of longstanding attenders, that membership in a church does not mean adherence to a particular doctrine but affirmation of a collective identity. Churchgoing and the associated organisations embody a collective discipline 
and a principle of exclusiveness and boundedness, but also a principle of inclusiveness with its emphasis on community. Respectability is the value of a person in their own eyes and in the eyes of society; it is value claimed and value granted. Some of these women wish to be identified with that quality of person; such a woman can then feel herself to be a full and complete person, within the terms of the local society in which she worships and is accepted as a full member.

A small subgroup of these individuals, however, are not particularly seeking that kind of respectability or stability, empowerment or healing, but have simply found a group of people who welcome them into their midst and provide them with company on a Sunday. These are the women who are the more ambivalent attenders. They have considered, if only to a limited extent, what churchgoing entails in terms of moral values and beliefs, and how worthwhile the church therefore is as an institution; finding this does not entirely accord with their own moral values and beliefs, they temper their frequency of attendance - or, alternatively, how they view what is happening during worship. They do, however, tend to participate with some regularity in the church's social calendar, if not in worship. In the following, to avoid repetition and for reasons of space, I shall present a series of 'ideal types', examples of the different reasons for returning that I have encountered. These are summarised in Table 1 below.

\section{Fully Committed Returners}

\section{Providing a Decent, Trustworthy Substitute Family}

Maura is a woman who is seeking a decent, trustworthy substitute for the traditional nuclear family, which has been missing in her life. She is the retired deputy head of a multi-ethnic comprehensive (non-selective) school in a large northern city and has also set up and run a small consultancy business dealing with educational matters. She was brought up in colonial East Africa, attending an Anglo-Catholic boarding school, only returning to the church after a long absence. This was through friends she met at a particularly difficult time in her life, just after a second divorce. They were churchgoers and encouraged Maura to join them. Now she has retired to the Lake District (southern Cumbria) and lives alone. She attends worship and sings in the choir in an ancient English priory: 'I love the sense of [...] in that building to feel that people have worshipped there for 800 years'. As she joins her voice to others for matins or choral evensong, the knowledge she is part of an unbroken line of worshippers for eight centu- 
ries fuses into one total experience of a continuous community still being sustained, leaving her with a strong sense of a still existing Christian England. Hervieu-Léger's (2000) community of memory, much less apparent in the multicultural city in which she has spent most of her professional life, is very much alive and well here, and now Maura, choir member and secretary of the Parochial Church Council (the governing body of the local congregation), feels very much part of it. Moreover, as an important member of this ancient village church, attracting hundreds of tourists throughout the year, a certain social status in her village accrues. Maura has thus regained something of the esteem she enjoyed in her working life in her retirement, a time when, for many, a certain loss of status is almost inevitable. Hence, we might argue that Maura has sought and has been granted a re-inauguration into respectability and public recognition of a desirable social identity.

She describes her present vicar as 'a good man, leading the church in the right direction'. He is married to a woman who could be said to embody the traditional English 'vicar's wife', with no paid work outside the home. Maura contrasts her total devotion to her husband and the needs of his church with other women she has met in her professional life. 'I seem to have got at 65 to the view that I'm coming back from this idea that women had to do this and had to have maternity leave for a year and ... I think for goodness sake, get back, back ... they've gone too far. They're on the way to making fools of themselves.' She feels that women 'should be gentler', and that if they read the bible they would see their true role models in women like Ruth and Mary. She quotes a woman priest she knows, whom she clearly admires because she is a 'highly intelligent woman, totally unaggressive and unfeminist but a very compassionate woman'.

In her interview, however, Maura presented a picture of herself as very self-possessed and self-motivated, jealously guarding her autonomy, a woman much influenced by second-wave feminism no less. Paradoxically, however, she is drawn to a church where there are stable traditional families, a vicar who is the acknowledged head of his household, a wife who is consistently self-sacrificing and a good mother to her children, even though Maura is not part of such a family herself and is 'better not married'. Smart (2007) speaks of the imaginary of family life, where nostalgic and idealised forms of the family are often recollected in evocation of 'proper' family life in bygone eras. For Maura, the 'proper' family of the vicar and his wife and children are present in the here and now, contemporary embodied examples of that imaginary, a family to live 'by' although certainly not to live 'with' 
(Gillis 1996, quoted in Smart 2007, 51 ). Having worked in a multicultural context in a large northern city for much of her professional life, Maura yearns for a return to what she perceives as a time of a Christian England, with its traditional morals and values, its rural way of life, and its strong sense of community bonds, although, interestingly, without wishing to espouse quite all of those traditional values herself.

\section{Providing a Sense of Stability and Moral Order}

In my next example, the need for family who can advise and offer guidance, or function as a symbol of Christian England, is much less evident in the respondent's agenda. Hers is more a need for a sense of order, where people are reliable and will not let her down, and with a form of service which is similarly reliable and ordered, part of a timeless tradition. For Brenda, attending the Anglican Church in a traditional village, although led by two evangelical vicars in the last two dozen years, is of prime importance, since it specifically maintains the type of good order she needs to anchor her life and worldview.

Brenda, a nominal Methodist, and her husband, a lapsed Catholic, moved to a Scottish island off the west coast to manage a village shop, but when a supermarket opened on the island their business was no longer viable. On hearing of the shop's imminent closure, certain politically motivated villagers, angry at their decision, began harassing and generally making a nuisance of themselves to Brenda and her family. Fortunately, hostility was not universal:

The person, one of the people that stood out was the minister, Alastair, and he didn't care whether we believed or what have you. He came round to see us and he would chat with us and he was so down to earth, you know, that I started going down to the church, then Pete [husband] started coming with me. We were going as a family. [ ... ] And we both sort of gave our lives to Jesus when we were there, and he was quite instrumental in all of that, was Alastair.

After they managed to sell their business, they moved to the Lake District and to St Matthew's, in a traditional Lakeland (Cumbrian) village. They met the vicar and his wife, who, along with other members, warmly welcomed them into the community and introduced them to the Alpha course. Brenda opted to become a full member of St Matthew's, while her husband joined 
a much more charismatic evangelical church. Brenda was unable to join him because she's 'overwhelmed about it, also undermined in a way that they're so charismatic about it all, I can't be. I just can't be like that.' She has settled for the local village church with its time-hallowed eight o' clock 1662 Prayer Book service, a form of words which has been repeated in Anglican churches, virtually unchanged, for over three centuries. This is because, as she expressed it, 'I like to know where I am'.

As we saw with Maura in the section above, for people like Brenda too the notion of the on-going worshipping community (including its Prayer Book), in some cases stretching back centuries, and certainly many decades, provides a sense of orderliness and stability in what can be a hostile world. Again, these communities are composed of what participants see as decent and trustworthy people, with certain moral standards, who can be relied upon to uphold those standards even when the world outside might be less than decent or reliable. The fact that the old liturgy can be accessed in its traditional form, if one opts for the right service, also provides a sense of continuity and wholeness, linking participants with that which is beyond and bigger, but also reminding them of their relation to all past members of the same unchanging community - Hervieu-Léger's (2000) chain of memory.

Brenda 'belongs' and is committed to her church. She is 'at home' in her traditional Anglican village church, but with a vicar leaning toward the evangelical, since together they convey a sense of tradition, moral order and predictability. She explicitly rejects her husband's choice of the charismatic because there the sense of order and predictability are not so apparent: she feels 'overwhelmed' and at the same time, 'undermined' by them. Thus, once again, it is belonging to this particular church that matters for Brenda, rather than any particular form of beliefs. As Jenkins (1999) also observes, these Christians are not so much defined by their beliefs as by their behaviours and character.

\section{Providing Support, Healing and Empowerment}

We have already seen examples of women who have (re)turned to the church at a time of disjunction or even crisis in their lives. Crisis and/or disjunction are also apparent in the life of the next participant, but she is not seeking a family, or the kind of order, desirable for Brenda. Rather, she is seeking a person who accepts her as she is, and who through this acceptance draws her into the worshipping community. Hence she is not only offered acceptance 
into a respectable community, but through this acceptance finds healing of past hurts and a sense of empowerment, leading to a more self-confident, fulfilled and fulfilling life.

Enid lived in the heart of 'swinging London', at the very height of the late sixties: a 'way out', sexually liberated, drug-fuelled scene. Liberation did not last long, however, and soon turned to alienation and severe depression. Enid's sense of abandonment began as a child, when her parents moved to southern Cumbria to open a hotel. 'It was horrible and I hated it and I wanted to go back home to the northeast and we couldn't.' All the while growing up, her sense of estrangement from 'home' and human relationships continued: 'I didn't really have any friends because I couldn't relate to anybody ... it was like everybody was going out and having fun, in inverted commas ... and if I tried to talk about what I was thinking about nobody wanted to know and home was where all the conflict was.'

While briefly at university, she met up with a man who introduced her to a whole range of alternative practices - and hippiedom. Enid ended up in London, trying one form of New Age therapy after another, getting into the drugs scene, getting married and divorced but never finding healing for her sense of isolation and emptiness. Somehow, she was drawn back to Christian ideas, although they did not go down well with her New Age friends, and Enid found herself continually drifting and searching, never quite 'fitting in'. Hers is a very long story. For the sake of brevity - and here I condense many pages of typescript - suffice it to say that Enid fell into a severe depression and a childhood illness returned, leading to her present disablement and inability to find suitable employment. At one particularly low point, and quite by chance, she met someone from the conservative evangelical Full Gospel Businessmen's Fellowship, who was willing to listen to her story and to offer her comfort and support over a period of several months, also encouraging her to return to church, as a place where she would be healed. Enid took his advice, and after she moved back to a small town in southern Cumbria she began attending one of the independent churches there. After a while she moved to a charismatic Anglican church, about twenty miles away, explaining:

I think the people in leadership there [the independent church] have a very limited life experience ... they're not capable of any depth of understanding .... of my experiences, my spiritual and searching experiences ... they just didn't understand the physical and emotional experiences I had had. They said they listened to the Holy Spirit but to be honest I think you need 
trained Christian counsellors because they didn't listen to people so they could hardly listen to the Holy Spirit, could they?

Belonging to this particular charismatic Anglican community, where people are actually trained in counselling, is exactly what Enid has been seeking, a place to tell her own individual story, warts and all, no longer feeling alienated, no longer cast off. Moreover, it is a church which welcomes single and divorced people, something Enid also prizes and compares with her previous experience at the independent church, where most people were married couples with children and where the emphasis was largely on catering for the young. For a divorced woman who has long been drifting, Enid has at last found a supportive community, a place to belong, a respectable community who convey respectability on her as well. This has also become apparent in the practical ways pointed out by Jenkins (1999): now living in permanent accommodation, she has a stable home, a sign of the independence and prosperity which characterise the respectable. She participates in the civic amenities of her town, as a respectable member of the community will do, quite often in the company of her once-estranged mother, so family relationships are beginning to heal too, another sign of respectability. As one who is beginning to feel healed and whole again, loved and valued in her worshipping community, with a new social identity, she is empowered to hold her head up in the local town community in which she now lives.

For women like Enid (as well as Wendy, whom we shall meet shortly), who have been hurt by difficult relationships or by enduring infidelity within marriage, women whom in the past society may have considered 'wayward' but who now seek to live differently, empowerment can be offered by significant churchgoing friends who provide a 'safe' environment of females, but also trustworthy males. These people will not seek to hurt or abuse them but will care for the vulnerable in a loving, non-sexual relationship. Here are people within a particular worshipping community who will affirm them as women and not regard them as sexual objects. Significant churchgoing others will listen and console, will acknowledge hurt and affirm them when in the past comfort has been visibly lacking. Significant churchgoing friends will also welcome them uncritically; thus the participants see their past as redeemed, as put behind them. They are welcomed into Jenkins' (1999) wider respectable community, the very community which in the past would, ironically, have perceived them as disreputable. 


\section{Less Committed Returning}

Finding an Alternative Form of Caring

Not all women seeking somewhere to belong, however, feel able to give full commitment to the church. For Wendy, it is simply that the church is not equipped to meet her particularly deeply seated needs; hence, although attending sometimes, she has turned elsewhere. As a child she had repeatedly suffered sexual abuse at the hands of a young farmworker, well known to her family. They never found out.

As I grew older I realised what a precious thing had been taken away ... It was my innocence, my childhood ... and ... he made me feel guilty for it ... I said I would never forgive him but in a way I sort of have, but it's taken a long time ... but I would never ... It affected everything I did. I was too frightened to go out with boys ... and ... I suppose we were going through the swinging sixties, hippies, free love and everything and I can remember ... girls at school getting up to all sorts of things at a very early age and me thinking: What idiots they are ... I just ... When I got older, through my teens er ... I was just ... frightened. It has affected my life a lot.

Wendy got married and divorced. While the divorce was pending she met another man, with whom she had a child and whom she eventually married. This second relationship, however, is far from harmonious. Her husband continues to have affairs with other women, verbally abuses her and generally treats her with condescension bordering on contempt. Her one consolation is her son, born to them before her divorce from her previous marriage. She remains where she is out of need for financial security, having little training or education beyond the minimum and little conviction that she could succeed on her own.

Wendy had gone to church as a child and even continued for a while as a young adult. On marriage to her first husband, however, attendance ceased. A sympathetic friend, whom she had met through her son's school, introduced her to her church and has accompanied Wendy on subsequent visits since the marriage about a dozen years ago. Wendy has attended periodically, but finds it difficult; now the friend has died, there is no one to accompany her. Meanwhile, Wendy has taken on the care of an elderly man with dementia, who occupies her time on Sundays as well as weekdays. This appears to be a relationship with a man which, in contrast to others, is proving therapeutic; thus it is perhaps not surprising that this takes precedence over churchgoing, which since the death of her friend is not the supportive and affirming experience it was. 
So, as I say, I feel I belong [to the church] and I feel I'm there but I don't feel I have to go and I feel really close to God when I go out ... even when I'm with Freddy [the man she cares for] and Freddy, you know, says various little things and I just feel this joy inside me and I think to myself: This is what it's all about. Very hard to explain. [...] He's very special.

But we should also note that for someone as traumatised as Wendy more than respectability is needed for healing to take place. Wendy's deep need for a therapeutic relationship is to some extent met, interestingly enough, through her caring for a vulnerable other, but outside the church. Hence attendance is sporadic.

\section{Looking for Affirmation of the Self}

I turn next to the example of Joan, who has also had to contend with deep psychological problems. She has suffered from bipolar disorder all her life, and consequently has spent much of it in isolation. Returning to church was more a means of dealing with her fear of meeting others than a need to be in a church specifically, which, as a child attending a strict Catholic primary school, Joan had found if anything intimidating. Her schooldays, with compulsory attendance at mass, have left her with a permanent sense of sin and guilt, which, even now, she finds difficult to lose: 'When you're in a deep depression the church doesn't help ... because you're conscious of $\sin . .$. I've imagined my soul getting all black.' McLeod (2007) draws attention to the criticism expressed in the sixties by some Church leaders in relation to the heavy emphasis on sin and guilt. He mentions Harry Williams, Dean of Trinity College, Cambridge, who saw this emphasis, for example in the Book of Common Prayer, as having a damaging psychological effect, and who called for the Church to adopt an ethic based on love rather than law.

In her late fifties Joan met a man through a dating agency, and they were married in his church, but otherwise she did not at first attend. She finally made an effort, through the prompting of a therapist on an anxiety management course. As she says, 'I'm still very socially phobic, it really grieves me ... it's left over from my manic depressive days.' Moreover, she adds, 'I do feel a hypocrite ... rather' [because] 'I'm not sure I believe in God'. When prompted, she expands: 'I think of punishment if I think of it at all ... I've done a lot of things I'm ashamed of ... I have a guilt complex ... more than that'. The Church's emphasis on sin and guilt, inculcated in Joan's childhood, and the ensuing damaging psychological effects to which Williams refers, seem to be in evidence here. Interestingly, both 'love' and 
'the law', to which he also refers, comparing the latter unfavourably to the former, are apparent in Joan's story. Recently she has been drawn a little further into the community, through the ministrations of a particularly warm-hearted elderly parishioner, who invites her to go through into the church hall for coffee after the morning service, an invitation Joan now sometimes accepts. She went on to say, however, that she was unhappy to be in church when she heard homophobic sentiments expressed by an elderly retired minister. Joan does attend, about once a month, particularly if her husband is there to encourage her - the operation of 'love' again - but it requires a considerable effort of will and evokes a degree of discomfort and dissonance if the 'wrong' preacher is in the pulpit, promulgating the Church's 'law' regarding sexual relations.

\section{Looking for Company on a Sunday}

Lucy, another pre-boomer, supplies another example of someone who is less committed, although for somewhat different reasons again. She too is not particularly seeking respectability, but simply company on a lonely Sunday morning. She attends, perhaps about once a month, but there are certain aspects of belief - as well as of values - about which she has thought, and which are not acceptable. McLeod (2007) refers to the greater openness to other new and more attractive belief systems which occurred in the cultural revolution of the sixties. Higher education generated new and more secular meaning systems, competing with theistic interpretations of the world through television programmes, such as Meeting Point, put out by the BBC; people had greater opportunities to hear alternative views on religion. Hence people have been led to think more carefully about the values and beliefs of their own institution, and to what extent they wish to be committed. Lucy had attended church very rarely until she moved to her present home in a small south-Cumbrian town, not long after which her husband died. She has very little family to call her own, with the loss of her husband she found herself particularly bereft. Moreover, as she said, 'Sundays are always the hardest day when you're on your own'. A neighbour introduced Lucy to her church, but she pointed out that she didn't go every week.

I never go the first Sunday of the month because I don't take communion because I'm not sure I believe. I'm honest. I'm not committed. If ever I do take communion you'll know I've become a member but as long as there's 
any doubt I'm just not happy ... I won't do it ... but I like to meet other people and they're very friendly.

Lucy has also reservations, she told me, about the value of maintaining the costly buildings in which many churches are housed. In the meantime, she felt that there was more to do now on Sundays in her small town; besides, the neighbour has died, so there is no prompting from that quarter. When asked if she would miss it if she did not go, she had no hesitation in saying, 'probably, although I'd probably find something to take its place' - a considerable contrast to women like Brenda and Maura. However, even the less committed like Lucy are often to be seen at church social events, voluntarily giving something back to the community that has supported them in their times of need. Their sense of connection is rather looser, there is much less a sense of commitment, but relationships within the church community are still valued - even if they are not invaluable in the way they are for some returners.

\section{Supporting Another But Finding One's Intellectual Commitment Elsewhere}

Betsy, the last returner, also values relationships but takes a more intellectual approach to churchgoing. She has indeed discovered new and more attractive forms of belief, and is prepared to question formerly respected ecclesiastical authorities, while remaining in the church; as McLeod (2007) suggests, this is typical of some women who have lived through the cultural revolution of the sixties.

Betsy went back to the church not because of any disjunction in her own personal life, but because such occurred in her late husband's. He 'caught' religion, she informed me, on becoming disabled, but his penchant for the charismatic evangelical did not suit Betsy; when he died, she returned to the high Anglicanism she had known as a child. She was also interested, however, in much less orthodox forms of belief, studying such writers as Joseph Campbell and Elaine Pagels and wanting to know more about the origins of the church and the import of the non-canonical literature of the early centuries CE. As a result of reading much of this literature, she finds herself today, she says, at odds with most of Anglican orthodoxy. Her yearning to explore and discuss religion and belief are much better met in the small group, part of the Progressive Christian Network Britain (see Lynch 2007 for a full discussion of such 'progressive spirituality' groups), which she attends fortnightly on a week-night. She describes herself as having, 
'[t]hese peculiar heretical thoughts. I often think I would have been burned at the stake if it had been two or three hundred years ago or whatever ... because there are so many things that I can't accept in the doctrine of the church which is why I say I'm hanging in by a thread really.' When I asked her why she still attended, she decided that

it still fulfils a need in me and I've almost got a loyalty to it. [...] I have this ... this is the hanging in to that childhood security I suppose but I love the candles and everything of that ilk. We have a Taizé service now and that to me, although there are only a handful of people. I wish we could build it up because that half hour is better than anything else I can do. And in that half hour I really feel that 'other', something other than ... which I can't say I do in a normal service.

For Betsy, high Anglicanism thus fulfils a need for a highly spiritual - somewhat nostalgic - experience, and for a sense of transcendence, but it does not satisfy her intellectually. However, there is another reason, which Betsy mentions rather quietly and after securing my guarantee that all this will be reported anonymously. Contrary to the other women in this chapter, she now attends not to receive support herself but to support another. He is a retired parish priest, a member of her congregation, and also gay. They spend a lot of time together, leading the congregation to believe they are more than 'just friends'; actually, apart from his friendship, which she values, she is providing cover for his homosexuality, unacknowledged within the congregation, as well as the same kind of (apparent) respectability some of the women above were seeking. Betsy connives at a 'cover-up', while having to 'reframe' spoken parts of the liturgy as 'symbolic', or simply not participate in it at all, and to derive her intellectual religious sustenance elsewhere, at the PCNB. It should be noted, incidentally, that for Betsy this group is an equally important component of her religious commitments, not an optional extra.

\section{Recent Perspectives on Religiosity}

Although some of these women mention beliefs, it appears that their churchgoing is characterised rather more in terms of values: those for example of warm relationships, respectability, stability, sobriety, or, for others, tolerance, intellectual curiosity and open-mindedness. We also note the variety of reasons for returning to the church. Talal Asad (2003) refers to Europeans 
standing in an (assumed) discursive Christian tradition, of religion being 'publicly present' (p. 5) in Britain, and part of what it has meant to live within the 'civilised' world (p. 165-6). However, people can be selective in how they approach their tradition. Nonetheless, according to Asad, this does not undermine 'their claim to its integrity' (p. 195). Nor does any attempt to adapt tradition to address new concerns in itself 'dissolve the coherence of that tradition' (p. 195). Other recent work in the sociology of religion underlines the need for a fresh approach to its study, in that past emphases on beliefs and ritual practices, bipolarities such as baptised and unbaptised, churchgoer and non-churchgoer, are insufficient to describe the current state of religiosity in the West. Grace Davie (2007a; b), for example, points to church attendance as a matter of choice and not obligation, as befits a culture of consumption. Meredith McGuire $(2007 ; 2008)$ urges us to consider 'lived religion' rather than religion as preached. Martin Stringer (2008) also focuses on the 'lived religion' of ordinary people, finding it more profitable to study the 'non-empirical' (p. 16); by this he means 'that which cannot be proved through any accepted methodology, in the thought and actions of a wide range of very different people'. People today may hold 'situational beliefs' (p. 51), something that 'fits' a particular situation for a particular time and which may be quite inconsistent with other beliefs they hold or those of official orthodoxy. It is a relationship that is sought, rather than an unequal encounter with awe-inspiring transcendence (p. 54-64). Those who are marginalised in society may well see religion as a way of coping with life's considerable vicissitudes (p. 76, 80-2), not a once-and-forall conversion or transformative experience, as traditional theology might suggest. Ole Riis and Linda Woodhead (2010) adopt another approach in considering the highly significant part that emotions play in religiosity. Too often, they say, we assume that emotions are private, personal and subjective inner states; in actual fact emotions are constructed in the interplay between social agents and structures, including those found within religion. They are also found in the 'ever-changing relations with complexes of cultural symbols and material settings' (p. 7). They stress the importance not only of social relations, including the supersocial, but also of relations with material objects, cultural symbols and environmental settings in what they term an 'emotional regime' (p. 21). Emotions (including religious ones) are involved in a triangulated relationship between the individual, society and symbolic/ material culture (p. 47-51).

Taking these new approaches into account with regard to this group of women, and following, first, Asad (2003), it appears that these women do 
return to a tradition of which they have long been part, even though not consciously practising it, and that to some degree they re-appropriate it, but not in its entirety; they adapt it, as he says, to address their own (new) concerns. Following Davie (2007a; 2007b), we note that this is church-returning occasioned by choice, not obligation. Some, troubled by the changes brought by contemporary times, and thereby incurring Giddens' (1990) 'tribulations of the self', have at some point made a personal decision to turn back to more traditional forms of worship and type of church; some are seeking a traditional family life through the church; some are seeking a place where one 'knows where one is', where people reliably hold the same moral values as oneself and will not let one down, a place with firm boundaries, where continuity, not change, is the watchword. Some are seeking the kind of oldfashioned respectability still conveyed by being a member of a worshipping community, spending time with people who are known to hold certain moral standards, decent upright citizens, known and valued in the local community. Some are seeking the kind of place, arising out of the needs of contemporary times, where the individual, with her unique problems and griefs, will be recognised and heard. Some simply seek company when the family is absent, as it so often is in these days of greater geographical mobility. Some want a spiritual experience without the religious element. Some do not want to attend regularly if it does not suit them, due to a clash either of values or of beliefs.

We might also argue this is religion as lived, not as preached, in that a number of these women are seeking relationship rather than transcendence, and in that beliefs relating to churchgoing, when mentioned, are rarely held unambiguously. Moreover, emotions are certainly implicated in these women's engagements and disengagements with religion, as the balance shifts and changes in the triangulation between the individual, social relations and the symbolic/material environment in which they find themselves.

Betsy remains in her high Anglican church on account of her friendship with a gay priest as well as her sense of connection to the high Anglicanism of her past, but most definitely not because she might espouse Anglican orthodoxy. Maura prizes the traditional family relationships within her ancient priory church, as evidenced in her vicar and his wife and family, while not wishing to be part of such a relationship herself. Lucy admits it is relationships she is seeking on a Sunday morning, when there is nothing much else to do and one lives alone. Joan attends as a way of coping with social phobia. In terms of situational beliefs, we see that Lucy refuses to attend on Sundays when participation in communion may be expected, 
because the beliefs it entails are unacceptable to her, but is happy to attend on an 'ordinary' Sunday morning. If she stops going she will probably find something else to take its place, but she believes sufficiently in the congregation as such to continue attending social functions of the church. Betsy consciously 'reframes' her beliefs in order not to suffer cognitive dissonance on Sunday mornings, finding her beliefs more readily in tune with the PCNB group she attends on weekdays. Joan has to make strenuous efforts to actually suspend her former beliefs in order to remain sitting in the congregation at all on Sundays. Brenda's beliefs, for example in the ancient Prayer Book, simply focus on her sense of being stabilised and grounded on Sunday morning.

Emotions certainly come into play in these women's engagement and disengagement with their worshipping communities and the symbolic/ material world of these communities. Wendy's is probably merely the most obvious of the various examples evidenced in this group of women. As she says, she 'feels' she is close to God, and she 'feels' she belongs to the church, but she doesn't 'feel' she needs to be there. And the reason for this is because she is now so emotionally engaged elsewhere, with someone who stirs in her one of the strongest of positive emotions we can experience: joy. As Riis and Woodhead (2010) suggest, what we have here are triangulated but also shifting relationships. Wendy the social actor is implicated in the negative social situations in which she has been/is humiliated both in the past and by her husband, but also in the positive supersocial relationship to God and the social and symbolic/material world of the church she has attended, offering her a degree of comfort. She is also implicated in the social relationship of care of the handicapped Freddy and the material/ symbolic environment, in which she offers physical hands-on caring while receiving special treatment in return. To return to McGuire $(2007 ; 2008)$ : Wendy's 'lived' religion is no longer attending church but tending to the needs of a handicapped man; it is this which makes her feel special, and which undoubtedly, in the caring relationship, contributes to her feeling close to God. Betsy, similarly, finds herself in a (platonic) social relationship with a gay priest, whose homosexuality cannot be acknowledged in this conservative congregation, but which certainly contributes to her remaining within the church - which at the same time provides a comforting reminder of the symbolic/material world of churchgoing in her past. She is also, however, implicated in the social relations of the PCNB group and the material/ symbolic world it represents. Applying Stringer's (2008) insight, I would argue that Betsy's 'beliefs' could be construed as 'situational'. There is on 
the one hand a willingness to conform, if only by her physical presence in the church on Sunday morning and by tapping into a hazily defined sense of transcendence, at least when a Taizé service is held. On the other hand, her 'true' beliefs are represented in the much more radical/liberal conversations and discussions of her week-night group meeting.

If these women are typical, it follows that we can no longer categorise religiosity in Britain into bipolarities, such as for example attenders and nonattenders. Nor can we any longer characterise religiosity simply in terms of traditional propositional belief or even ritual practices, but rather must pay much more attention to 'situational' beliefs and values and to how people 'live' their religion. The highly significant part played by the emotions in the shifting engagements and disengagements of churchgoers also needs to be factored into an accurate account, while Davie's (2007a; 2007b) assertion that even churchgoers exercise their sovereign rights as a consumer seems to hold good here. I am of course describing a very small number of women; much more research is needed to see if these patterns are repeated for example in different (more urban) settings, other age groups and among men. But they do suggest that adopting these kinds of approaches to the characterisation of what constitutes religious commitment in contemporary times is likely to present us with a much more accurate picture of the sacred landscape in present-day Britain.

\section{Conclusion}

The article has considered a group of women who have rarely figured in the sociology of religion literature and about whom very little is known: those who return to churchgoing after a period of disaffiliation. Rehabilitated returners return to church because they seek a broader sense of belonging. They have returned with another churchgoer at a time of disjunction or a turning point in their lives. For a number of these women, being (re)admitted into the worshipping community is a mark of being (re)-admitted to respectability. In one case, a participant confers that respectability on another. Being accepted and valued in the community is not a one-way process. As the women are offered a welcome, friendship, guidance, support, encouragement, healing, they are also offering forms of care to others, supporting a prayer partner and giving time to church events and affairs. All these women have lived through the cultural revolution of the sixties; but far from bringing a sense of liberation, as has been asserted by some commentators, such as Brown $(2001 ; 2006 ; 2010)$, what is experienced in one 
form or another is a sense of alienation, what Giddens (1990) has referred to as the 'tribulations of the self' (p. 181). Hence the church has been a place to repair to, a repository of traditional moral values and time-honoured order, enshrined in age-old liturgy and hallowed stones, where the chain of memory (Hervieu-Léger 2000) is still preserved and to some degree persists. One is accepted into what Jenkins (1999) calls a 'respectable' community, of decent, civic-minded, independent and stable citizens, people who are known and valued in the local community.

Some returners, however, possibly more influenced by the changed moral norms and values of the sixties cultural revolution, are no more than sporadic attenders. For them, some forms of belief and/or the moral values of the church community are found to be wanting. The problems of some women, such as Wendy for example, are so deep-seated that churchgoing on its own is insufficient to address them, and they too may be no more than sporadic attenders.

The analysis of such returners is considerably enhanced by adopting some of the newer approaches to the characterisation of religiosity, which take into account lived experience rather than studying what is preached to churchgoers from the pulpit and in theological texts. Tradition may be re-appropriated but adapted to one's needs (Asad 2003). Analysing commitments in terms such as those advocated by Davie (2007a; 2007b) and the culture of choice, McGuire (2007; 2008) and lived religion, Stringer (2008) and the non-empirical approach, and Riis and Woodhead (2010), paying attention to the role of the emotions, can only refine and further develop a subject of study which is certainly not contained in the counting of numbers and the tabulating of statistics, if indeed it ever was.

\section{Bibliography}

Asad, Talal

2003 Formations of the Secular: Christianity, Islam, Modernity. Stanford, CA: Stanford University Press.

\section{Barker, Eileen}

1994 But Is It a Genuine Religion? - A. L. Greil \& Thomas Robbins (eds), Religion and the Social Order, Vol 4: Between Sacred and Secular: Research and Theory on Quasi-Religion, 69-88. Greenwich, CT and London: JAI Press Inc. 


\section{Brierley, Peter}

2001 Ups and Downs of Attendance.

2003 Turning the Tide: The Challenge Ahead: Report of the 2002 Scottish Church Census. London: Christian Research.

2010 Future First: Providing Facts for Forward Planning. Tonbridge, Kent: Brierley Consultancy.

2006 UKCH Religious Trends No.6 2006/7. London: Christian Research.

Brown, Callum G.

2001 The Death of Christian Britain: Understanding Secularization 1800-2000. London and New York: Routledge.

2006 Religion and Society in Twentieth-Century Britain. Harlow: Pearson Education Ltd.

2010 Women and Religion in Britain: The Autobiographical View of the Fifties and Sixties. - Callum G. Brown \& Michael Snape (eds), Secularisation in the Christian World, 159-74. Farnham and Burlington, VT: Ashgate.

Brown, Callum G. \& Michael Snape (eds)

2010 Secularisation in the Christian World. Farnham and Burlington VT, Ashgate.

Bruce, Steve

2002 God Is Dead: Secularization in the West. Oxford: Blackwell.

\section{Burger, Thomas}

1976 Max Weber's Theory of Concept Formation: History, Laws and Ideal Types. Durham, NC: Duke University Press.

\section{Clarke, Simon}

2001 Ideal Type: Conceptions in the Social Sciences. - N. J. Smelser \& P. B. Bates (eds), International Encyclopedia of the Social and Behavioral Sciences, 7139-48. Amsterdam and Oxford: Elsevier.

\section{Crockett, Alasdair \& David Voas}

2006 Generations of Decline: Religious Change in 20th-Century Britain. Journal for the Scientific Study of Religion 45 (4), 567-84.

\section{Davie, Grace}

2006 Is Europe an Exceptional Case? - The Hedgehog Review, 23-35.

2007a The Sociology of Religion. London, New Delhi, Singapore and Thousand Oaks, CA: Sage Publications.

2007b Vicarious Religion: A Methodological Challenge. - Nancy Ammerman (ed.), Everyday Religion: Observing Modern Religious Lives, 21-35. Oxford \& New York: Oxford University Press.

\section{Dex, Shirley}

1991 Introduction: Life and Work History Analyses. - Shirley Dex (ed.), Life and Work History Analyses: Qualitative and Quantitative Developments, 1-19. London and New York: Routledge. 


\section{Eccles, Janet B}

2010a How Have Preboomer and Boomer Women Raised in Christianity Who Have Lived through the 'Sixties Revolution' Been Affected in Terms of Their Religious and Value Commitments? An Interview-Based Study with Informants from South Cumbria. PhD thesis. Lancaster: Lancaster University.

2010b Le Inglesi Che Vanno in Chiesa: Le Ultima Di Una Longa Storia? Etnografia e Ricerca Qualitativa 2010 (1), 88-106.

\section{Giddens, Anthony}

1990 Modernity and Self-Identity. Cambridge: Polity Press.

\section{Gillis, John R.}

1996 A World of Their Own Making: Myth, Ritual, and the Quest for Family Values. Cambridge, MA: Harvard University Press.

Heelas, Paul \& Linda Woodhead with Benjamin Seel, Bronislaw Szerszynski \& Karin Tusting

2005 The Spiritual Revolution: Why Religion Is Giving Way to Spirituality. Malden, MA and Oxford: Blackwell Publishing.

\section{Hervieu-Léger, Danièle}

2000 Religion as a Chain of Memory. Cambridge: Polity.

\section{Jenkins, Timothy}

1999 Religion in Everyday Life: An Ethnographic Approach. New York and Oxford: Berghahn Books.

\section{Lynch, Gordon}

2007 The New Spirituality: An Introduction to Progressive Belief in the TwentyFirst Century. London and New York: I B Tauris.

\section{Marler, Penny Long}

2008 Religious Change in the West: Watch the Women. - Kristin Aune \& Sonya Sharma \& Giselle Vincett (eds), Women and Secularization in the West: Challenging Seularization. Aldershot and Burlington, VT: Ashgate.

\section{McGuire, Meredith B.}

2007 Embodied Practices: Negotiation and Resistance. - Nancy Ammerman (ed.), Everyday Religion: Observing Modern Religious Lives, 187-200. Oxford and New York: Oxford University Press.

2008 Lived Religion: Faith and Practice in Everyday Life. Oxford and New York: Oxford University Press.

\section{McLeod, Hugh}

2007 The Religious Crisis of the 1960s. Oxford and New York: Oxford University Press. 
Peters, H. E.

1989 Retrospective Versus Panel Data in Analyzing Lifecycle Events. Journal of Human Resources XXIII (4), 201-13.

Riis, Ole \& Linda Woodhead

2010 A Sociology of Religious Emotion. Oxford: Oxford University Press.

Smart, Carol

2007 Personal Life: New Directions in Sociological Thinking. Cambridge and Malden, MA: Polity.

Stringer, Martin D.

2008 Contemporary Western Ethnography and the Definition of Religion. London and New York: Continuum.

Voas, David

2006 Religious Decline in Scotland: New Evidence for Timing and Spatial Patterns. - Journal for the Scientific Study of Religion 45 (1), 107-18.

Voas, David \& Alasdair Crockett

2005 Religion in Britain: Neither Believing nor Belonging. - Sociology 39 (11), 11-28.

\section{Appendix. Table 1: Varieties of rehabilitated returners}

\begin{tabular}{|l|l|}
\hline $\begin{array}{l}\text { Returning with full commitment to } \\
\text { all aspects of church life }\end{array}$ & Less committed returning \\
\hline $\begin{array}{l}\text { Providing a decent, trustworthy substi- } \\
\text { tute family } \\
\text { Maura }\end{array}$ & $\begin{array}{l}\text { Finding an alternative caring com- } \\
\text { mitment } \\
\text { Wendy }\end{array}$ \\
\hline $\begin{array}{l}\text { Providing a sense of stability and moral } \\
\text { order } \\
\text { Brenda }\end{array}$ & $\begin{array}{l}\text { Looking for affirmation of the self } \\
\text { Joan }\end{array}$ \\
\hline $\begin{array}{l}\text { Providing support, healing and empow-w- } \\
\text { erment }\end{array}$ & $\begin{array}{l}\text { Looking for company on a Sunday } \\
\text { Enid }\end{array}$ \\
\hline & $\begin{array}{l}\text { Lucy } \\
\text { intellectual commitment elsewhere } \\
\text { Betsy }\end{array}$ \\
\hline
\end{tabular}

